\title{
MODIFICATION OF FAO CROP MODEL TO SIMULATE YIELD RESPONSE TO WATER FOR PEACH TREES
}

\author{
S. M. Ismail ${ }^{1}$, T. K. Zin El-Abedin ${ }^{1}$, D. O. El-Ansary ${ }^{2}$ and A. Abd El-Al ${ }^{3}$
}

\section{A BSTRACT}

Although, as compared to other crop models, AquaCrop has a significantly smaller number of parameters and a better balance between simplicity, accuracy and robustness, AquaCrop model is not yet available for fruit trees. So, AquaCrop model was studied and modified to suit the deciduous fruit trees such as peaches under drip irrigation system and the conditions of light soil in the arid and semi arid climate. The modified model is able to simulate the growth cycle of the deciduous fruit trees and estimate the yield under different stress condition. After that, a computer program was planned and developed with easy interface and few requirements to estimate the resulting yield by means of yield response factors under different stress condition. To validate the simulation program, two seasons experiment were designed to determine the yield for peach trees (Prunus persica) which is as an example of a deciduous tree, under water stress conditions by two different techniques Partial root-zone drying (PRD) and Regulated deficit irrigation (RDI) in the west noubaria rural development project research station. PRD and RDI are examples of new water-saving irrigation strategies used for reducing applied irrigation water. These techniques have been successfully adopted to produce many crop and fruit species and improve the water use efficiency. The validation of simulation program was performed using the results of an experiment peach field in 2011 and 2012 seasons. The simulated yield was close to those measured; with index of agreement $(d)$ and correlation coefficient $(r)$ were close to 1 in both seasons. Also, the simulation program was tested to simulate the peach fruit yield under different irrigation deficit percentages

1 Prof. Dr. of irrigation systems, Agric. Eng., Fac. of Ag., EL-Shatby, Alex. Univ.,Egypt. 2 Dr. of Pomology, Precision Agric. Lab., Fac. of Ag., EL-Shatby, Alex. Univ.,Egypt. 3 Assistant Lecturer., Agric. Eng., Fac. of Ag., EL-Shatby, Alex. Univ.,Egypt. 
Also, the simulation program was tested to simulate the peach fruit yield under different irrigation deficit percentages using PRD and RDI techniques, $100 \%$ to $30 \%$ of the irrigation control treatment water volume, during the slow fruit growth phase until the maturity. Yield response factor corresponding to the levels of shortage of irrigation water was determined in RDI and PRD strategy, were 1.32 and 0.72, respectively.

Keywords: AquaCrop model, Partial root-zone drying, Regulated deficit irrigation, Peach trees ( Prunus persica).

\section{INTRODUCTION}

aes Dirk et al. 2011 defined the yield response to water (the
yield response factor (Ky)) that describes the relationship
between crop yield and water stress as a result from insufficient supply of water by rainfall or irrigation during the growing period. Steduto et al. 2011 showed that the yield response factor is representing the effect of a reduction in evapotranspiration on yield losses. FAO addressed the relationship between crop yield and water use in Paper n. 33 (Doorenbos and Kassam, 1979) proposing a simple equation where relative yield reduction is related to the corresponding relative reduction in evapotranspiration (ET). Specifically, the yield response to ET is expressed as:

$$
\left(1-\frac{Y_{a}}{Y_{m}}\right)=K_{y} \times\left(1-\frac{E T_{a}}{E T_{m}}\right)
$$

Where:
Ya actual yield (ton/ha);
Ym maximum yield (ton/ha);
ETa actual evotranspiration ( $\mathrm{mm})$;
ETm maximum evapotranspiration $(\mathrm{mm})$;
ky yield response factor.

The yield response factor (Ky) captures the essence of the complex linkages between production and water use by a crop, where many biological, physical and chemical processes are involved. The 
relationship has shown a remarkable validity and allowed a workable procedure to quantify the effects of water deficits on yield.

Moutonnet, P. 2002 Stressed that when water deficit occurs during a specific crop development period, the yield response can vary depending on crop sensitivity at that growth stage. Therefore, timing the water deficit appropriately is a tool for scheduling irrigation where a limited supply of water is available.

Mannocchi and Mecarelli (1994) showed that, using Eq.(1), it was possible to model relationships between crop yield and water applied. These relationships acted as a constraint in a mathematical programming framework, with the aim of optimizing (in economic terms) the application of available irrigation water, taking into account the possibility of varying the cropping pattern. An optimal solution was possible only on an annual basis; there was an attempt to define a method for determining a single, constant and optimal solution.

FAO has been developing a yield-response to water model "AquaCrop". The model treats herbaceous crops and tree crops separately, and simulates growth of a crop species, striving to address conditions where water is a key limiting factor.

Maintaining the original concept of a direct link between crop water use and crop yield, the AquaCrop model evolved from the FAO I\&D Paper No. 33 approach by separating non-productive soil evaporation (E) from productive crop transpiration $(\mathrm{Tr})$ and estimating biomass production directly from actual crop transpiration through a water productivity parameter

As compared to other crop models, AquaCrop has a significantly smaller number of parameters and a better balance between simplicity, accuracy and robustness. AquaCrop model has a number of weaknesses where it is not yet available for fruit trees and not recommendable under saline conditions. 
Through the study of simulation model which presented by the Food and Agriculture Organization " FAO" to estimate the yield response to water for field crops and also the difficulties that led to was not used with fruit trees, modifications have been conducted to this model to be able to estimate yield response to water for deciduous fruit trees.

These modifications are based on that the green canopy cover of deciduous trees started grow in the last flowering stage and continues to grow through the spring and summer and loses all its leaves in the fall and winter

Also, the values of the constants for the tree will be different depending on the age of the tree, such as maximum percentage of canopy cover, shaded area and crop coefficient.

Therefore the aimed of the current study is study and modify the simulation model to estimate the yield response to water for field crops which presented by the Food and Agriculture Organization " FAO" to suit the deciduous fruit trees such as apples, nectarines, peaches, pears and plum under drip irrigation system and the conditions of light soil in the arid and semi arid climate. Hence, a computer program has to be planned and developed with easy interface and few requirements to estimate the resulting yield by means of yield response factors under different stress condition.

The peach tree, Prunus persica, is as an example of a deciduous tree, native to China, where it was first cultivated. It bears an edible juicy fruit called a peach. The species name persica refers to its widespread cultivation in Persia, whence it was transplanted to Europe. It is classified with the almond in the subgenus Amygdalus, distinguished from the other subgenera by the corrugated seed shell. It belongs to the subfamily Prunoideae of the family Rosaceae.

Peach is one of the most widely cultivated and important deciduous fruit trees in the world. The main producing country is China, which 
represents 50 percent of the world peach production. Production in China rose spectacularly over the last decades from 380000 tone in 1970 and an average yield of 3.6 tone/ ha to over 10 million tone in 2011 with an average yield of 14.4 tone/ ha, followed by Italy, there were over 1.5 million ha of peach and nectarine globally with an average yield of 13.0 tone/ha. Egypt is the twelfth producer in the world, producing 0.3 million tones in 2011 and peach fruits are considered among the important export crops to Europe (FAO, 2012).

To evaluate the effects of water stress in Peach trees, partial root zone drying and regulated deficit irrigation techniques were used. Regulated deficit irrigation (RDI) and partial root-zone drying (PRD) are examples of strategic irrigation management techniques in the world used for reducing applied irrigation water. Both of these methods have proven success with many of the crops in spite of the shortage of yield as a result of reduced irrigation water.

Regulated deficit irrigation is the practice of using irrigation to maintain plant water status within prescribed limits of deficit with respect to maximum water potential for a prescribed part or parts of the seasonal cycle of plant development. The aim in doing this is to control reproductive growth and development, vegetative growth and/or improve water use efficiency (Kriedemann et al. (2003)).

Partial root-zone drying subjects one-half of the root system to dry or drying phase while the other half is irrigated. The wetted and dried sides of the root system alternate on a 10-14 day cycle (McCarthy et at. (2002)). In most cases, PRD irrigation has shown a great potential to increase IWUE and to maintain yield (Davies and Hartung, 2004).

So, the objectives of the present study were to:

- Determine the effects of RDI and PRD techniques on peach yield.

- Develop and validate a simulation model that can estimate the resulting yield for peach trees under different stress condition. 


\section{MATERIALS AND METHODS}

\section{Experimental procedure}

A field experiment was conducted in the West Noubaria Rural Development project research station in " Elesraa Wa Al Miraj " Village, $113 \mathrm{~km}$ on the Cairo-Alexandria Desert Road. The site soil was almost homogeneous and the soil texture was classified as sandy loam soil.

Two seasons experiment were designed to compare the effects of six irrigation treatments, which resulted from the combination of Control, Partial root-zone drying (PRD) and regulated deficit irrigation (RDI), on the yield quantity of the peach tree (Prunus persica). These treatments were initiated each season at end of March at the slow fruit growth phase (pit hardening) and stopped at mid of May at the beginning of peach harvest.

Irrigation control treatment $(\mathrm{C}=$ full irrigation) was scheduled according to a crop water balance technique. The RDI treatments consisted of two percentage level " $\mathrm{RDI}_{75}$ and $\mathrm{RDI}_{50}$ "which received 75 and $50 \%$ of the irrigation control treatment water volume respectively. The PRD treatments consisted of three percentage level " $P R D_{100}, \mathrm{PRD}_{75}$ and $\mathrm{PRD}_{50}$ "which received 100, 75 and $50 \%$ of the irrigation control treatment water volume respectively. The dripper lines of PRD treatments were worked alternately every 7 days.

The cultivar of peach trees planted was called Early Swelling. The peach fruit flesh is creamy white and is a free stone cultivar. During 2011, the peach trees were 2 years old. Tree spacing was $4.5 \times 1.5 \mathrm{~m}$ and the trees were pruned to a $(\mathrm{Y})$ system with two main branches. The tree dripper lines spacing was one meter. Pesticides and regular fertilization were added in the specific dates and quantities.

The experimental layout was a randomized complete-block design. The experimental area $(27 \mathrm{~m} * 36 \mathrm{~m})$ was divided into six treatments with three block-replicates per treatment as shown in Fig. (1). 


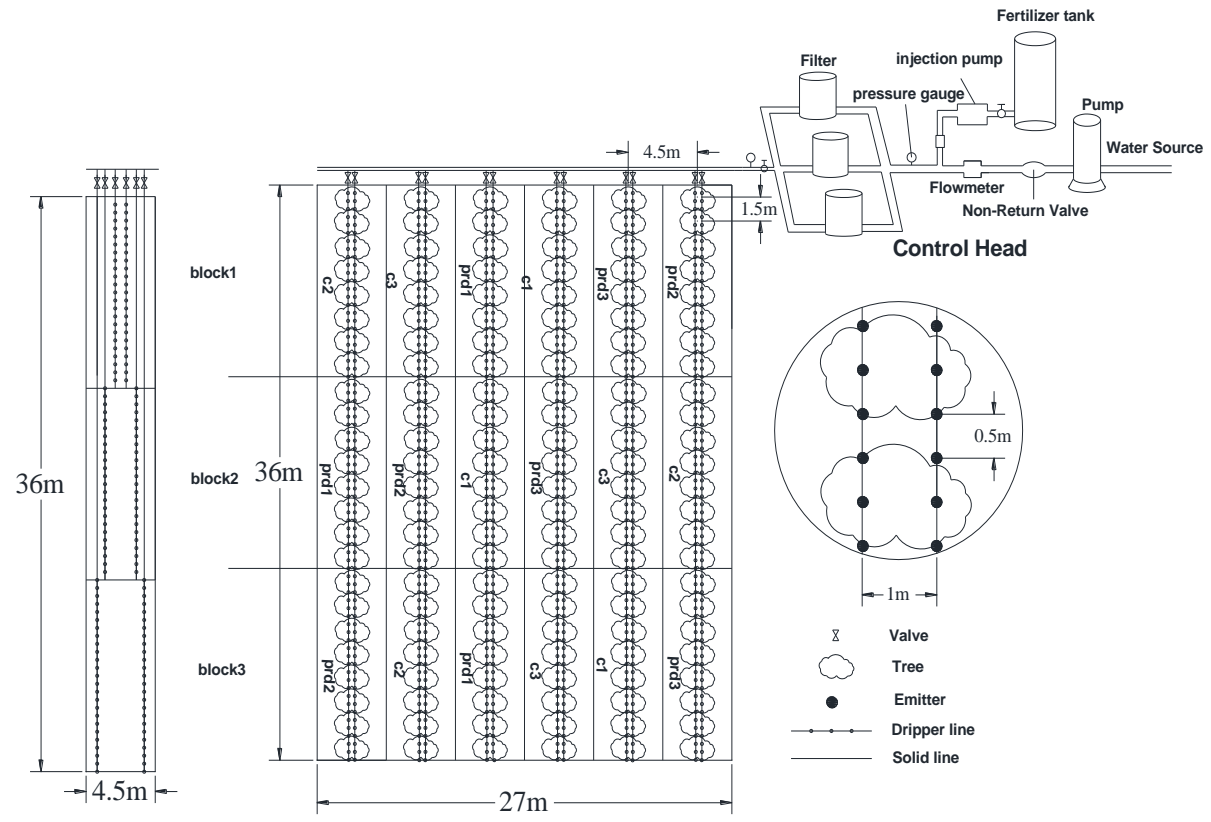

(b)

(a)

Fig.1. Field experimental area layout, a- Treatments distribution, bDripper lines installation in one of the trees lines.

The amount of irrigation and application time was calculated based on climatic data using the water budget approach methodology. Climatic data was determined by daily climate data recorder through WatchDog model 2900ET weather station. The WatchDog model 2900ET can measure, calculate and $\log$ most standards of weather in addition to evapotranspiration (ETo).

The harvest was done manually and weights of fruits produced were measured for each treatment and converted to tons per hectare.

\section{Model Development}

- Green canopy cover

The development and senescence of the green canopy under optimal conditions is described by four parameters (Steduto et al., 2009). These parameters have been modified as follows:

CCo, initial canopy cover percentage, for the deciduous fruit tree was considered at the lowest possible value $(\mathrm{CCo}=0.1 \%)$. 
CGC, canopy growth coefficient (percentage ground cover increase per day), and CDC, canopy decline coefficient (percentage ground cover decline per day), were simulated according to FAO model.

$\mathrm{CCx}$, maximum canopy cover percentage under optimal conditions depends on how the growth of the tree (shaded area), tree spacing and tree old. For no stress and optimal conditions, the canopy cover will reach the maximum canopy cover appropriate to the age of the tree.

Mature orchards and vineyards generally have lower ground cover values. So to calculate the percent of amended ground cover and which make the value of evaporation and transpiration calculated correctly, a new coefficient is needed. The ground cover coefficients $(\mathrm{Kr})$ were chosen referring to Fereres and Castle, (1981). The $\mathrm{Kr}$ is related to the horizontal projection of the tree shade. This coefficient is approaching twice the percentage of ground covered by the shade of the trees (Fereres et al.,1982, Orgaz and Fereres, 1998 and Steduto et al. 2012). Accordingly, Moral et al., 2009 determined $\mathrm{Kr}$ from the following equation:

Where

$$
K_{r}=\frac{2 \times S_{c}}{100}
$$

$\mathrm{S}_{\mathrm{c}} \quad$ the percentage of ground covered by the shade of the trees.

So, CCx which equivalent to $\mathrm{K}_{\mathrm{r}}$ in this model is determined by diameter of shaded area and tree spacing as follows:

Where:

$$
C C x=\frac{2 \pi D^{2}}{4(S r \times S p)} \times 100
$$

D diameter of shaded area (m);

$\mathrm{Sr} \quad$ row spacing $(\mathrm{m})$;

Sp plant spacing $(\mathrm{m})$.

- Effective rooting depth

The effective rooting depth is defined as the soil depth where root proliferation is sufficient to extract most of the crop water demand.

In trees, root growth is between declined and increased alternately. Root growth declined during the fruit growth and defoliation period and increased after harvest and before fruit growth period. Roots were mostly 
located in the upper $0.55 \mathrm{~m}$ of soil and were particularly concentrated at 0.40-0.55 m (Abrisqueta et al., 2008). In this model, will be considered that the depth of the roots stop growing after reaching a maximum depth after the flowering stage.

- Soil water balance

Following the steps of Raes et al., 2009 and Raes et al., 2012, The model divides both the soil profile and time into small fractions. As such the one-dimensional vertical water flow and root water uptake can be solved by means of a finite difference technique (Carnahan et al., 1969; Bear, 1972). The simulation starts with the drainage of the soil profile. Subsequently water infiltrates into the soil profile and finally the amount of water lost by soil evaporation and tree transpiration is calculated.

- Stress

Tree growth is affected by different stress. In this model, air temperature stress and soil water stress will be considered only.

- Air temperature stress

Production of biomass might be affected by air temperature stress. Cold stress coefficient (Ksb) determines the degree of biomass production reduction. Stress indicators for air temperature stress are growing degrees days $(\mathrm{GDD})$. The process is completely halted $(\mathrm{Ksb}=0)$ at and below the lower threshold, and not affected $(\mathrm{Ksb}=1)$ at and above the upper threshold. For air temperatures stresses a logistic shape of the Ksb curve is considered.

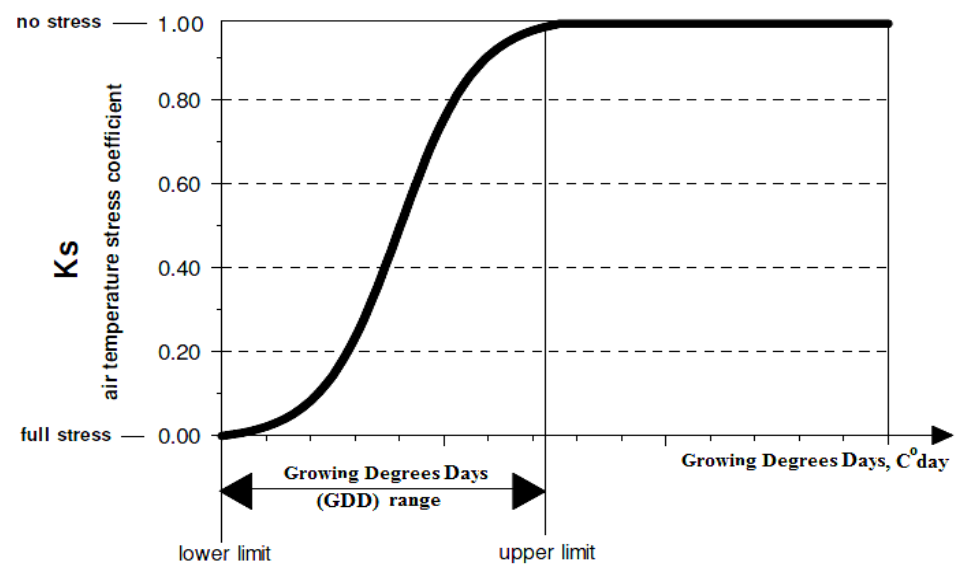

Fig.2. The cold stress coefficient (Ks) for various air temperatures (Raes et al., 2009). 


\section{- Soil water stress}

Soil water stress affects the development of the canopy cover, which results in stomata closure and a reduction of crop transpiration rate, and alters the Harvest Index. If the soil water stress is severe it can trigger early canopy senescence. Soil water stress affects the above processes when the stored soil water in the root zone drops below a threshold level (P). The soil water stress coefficients effects on tree growth are presented in Table (1).

Water stress starts to affect the process when the soil water content drops below the upper threshold. At the lower threshold the effect of water stress is at its full strength. Each of the processes affected by soil water stress has its own threshold levels. For leaf and hence canopy growth $\left(\mathrm{Ks}_{\text {exp,w }}\right)$ the lower threshold is above PWP, where as for stomata closure $\left(\mathrm{Ks}_{\mathrm{sto}}\right)$ and senescence $\left(\mathrm{Ks}_{\mathrm{sen}}\right)$ the lower threshold is fixed at PWP. The shape of the Ks curve can be linear or convex (Raes et al., 2012).

Table 1. Soil water stress coefficients and their effect on crop growth.

\begin{tabular}{|c|c|c|}
\hline $\begin{array}{l}\text { Soil water stress } \\
\text { Coefficient }\end{array}$ & Direct effect & $\begin{array}{l}\text { Target Model } \\
\text { Parameter }\end{array}$ \\
\hline $\begin{array}{l}\mathbf{K s}_{\text {aer }} \\
\text { Soil water stress } \\
\text { coefficient for water } \\
\text { logging (aeration } \\
\text { stress). }\end{array}$ & Reduces crop transpiration & $\operatorname{Tr}_{\mathrm{x}}{ }^{*}$ \\
\hline $\begin{array}{l}\mathbf{K s}_{\text {exp,w }} \\
\text { Soil water stress } \\
\text { coefficient for } \\
\text { canopy expansion. }\end{array}$ & $\begin{array}{l}\text { Reduces canopy expansion and } \\
\text { (depending on timing and strength of } \\
\text { the stress) might have a positive } \\
\text { effect on the Harvest Index }\end{array}$ & $\begin{array}{l}\text { CGC and } \\
\text { HI }\end{array}$ \\
\hline $\begin{array}{lr}\mathbf{K s}_{\text {sen }} & \\
\text { Soil water stress } \\
\text { coefficient ror } \\
\text { canopy senescence }\end{array}$ & $\begin{array}{l}\text { Reduces green canopy cover and } \\
\text { hence affects crop transpiration }\end{array}$ & $\mathrm{CC}$ \\
\hline $\begin{array}{l}\mathbf{K s}_{\text {sto }} \\
\text { Soil water stress } \\
\text { coefficient for } \\
\text { stomatal closure. }\end{array}$ & $\begin{array}{l}\text { Reduces crop transpiration and the } \\
\text { root zone expansion, and (depending } \\
\text { on timing and strength of the } \\
\text { stress) might have a negative effect } \\
\text { on the Harvest Index }\end{array}$ & $\mathrm{Tr}_{\mathrm{x}}$ and $\mathrm{HI}$ \\
\hline
\end{tabular}

$* \operatorname{Tr}_{\mathrm{x}}=$ Max. Crop Transpiration 
-Biomass production

The daily (m) and the cumulative (B) biomass production are obtained from the normalized water productivity (WP*), and the ratio of the daily crop transpiration (Tr) over the reference evapotranspiration for that day (ETo) as follows:

$$
B=K s_{b} \times W P^{*} \sum\left(\frac{T r}{E T o}\right)
$$

Where $\mathrm{Ks}_{\mathrm{b}}$ is an air temperature stress coefficient which becomes smaller than 1, and reduces biomass production, when it becomes too cold to guarantee a specific number of growing degrees in the day (Raes et al., 2009).

- Partition of biomass into yield part (yield formation)

The partition of biomass into yield part $(\mathrm{Y})$ is simulated by means of a Harvest Index (HI) (Raes et al., 2009):

$$
\mathrm{Y}=\mathrm{HI} \times \mathrm{B}
$$

Where $\mathrm{B}$ is the total above-ground biomass produced at fruit maturity and $\mathrm{HI}$ the fraction of $\mathrm{B}$ that is the yield part. When water and/or temperature stress develops during the growth cycle, the Harvest Index is adjusted to the stresses at run time for fruit producing and might be different from the reference harvest index (HIo). The adjustment can be positive or negative and depends on the timing and the extent of the stress.

\section{Computer Program}

The simulation model was developed using Visual Basic language, version 2008, with a well developed user interface and multiple graphs and schematic displays in the menus help the user to discern the consequences of input changes and to analyze the simulation results. This model is called "Fruit tree" and have the compatibility to work in any PC with all version of Microsoft Windows until windows7.

The program is composed of a set of interfaces describing the various processes involved in tree development, stresses experienced by the tree, irrigation schedules and soil water balance. The main output of the 
program is to estimate the resulting yield by means of yield response factors under different stress condition.

The climatic data consists of daily ETo (reference crop evapotranspiration), Rainfall observations and degrees maximum and minimum temperature With the possibility of calling the data reserved from previous years and represented graphically.

By specifying and selecting a few appropriate tree parameters in the menu interface, the program creates a complete set of parameters that can be describe the vegetative growth and root of the tree with the addition of some of the stresses that may be exposed to tree.

The soil profile may be composed of number of soil horizons with specific characteristics for each. The program contains a complete set of default characteristics that can be selected and adjusted for various types of soil or the user can input its own specific soil values.

The Irrigation scheduling interface proposes options related to drip irrigation system and the user can define its own schedule on the basis of specific depth or timing, or let the model to automatically generate the scheduling on the basis of water consumed by the tree.

The program simulates the soil water balance and the yield expected in the specified climate, crop and soil environment and for the specified irrigation option and presents some of outputs during the simulation process and some of them at the end of the simulation process, including:

- The daily climatic data (evapotranspiration, rainfall and maximum and minimum temperature) over the growing cycle.

- The evolution of green canopy cover and crop transpiration over the growing cycle.

- The water content in the soil profile and water balance elements.

- Actual yield (ton /ha) and Irrigation water use efficiency (Kg (yield) / $\mathrm{m} 3$ irrigation water). 
The functional relationships between the different model components are depicted in Fig.(3). Chart of model indicating the main components of the climate, crop, soil and management and the parameters driving canopy cover, stress, soil water balance, transpiration, biomass production, and final yield. Continuous lines indicate direct links between variables and processes. Dashed lines indicate feedbacks.

\section{Model Validation}

The model was tested on field experiments of peach trees yield resulting from season 2011 and 2012. As mentioned the computer program needs four data group for simulation: Climate data, Crop data, Soil data, and irrigation data. The conservative (constant) and generally applicable parameters for the simulation of peach productivity are given in the following Table 2 .

For the performance evaluation of the model, the following statistical parameters were used:

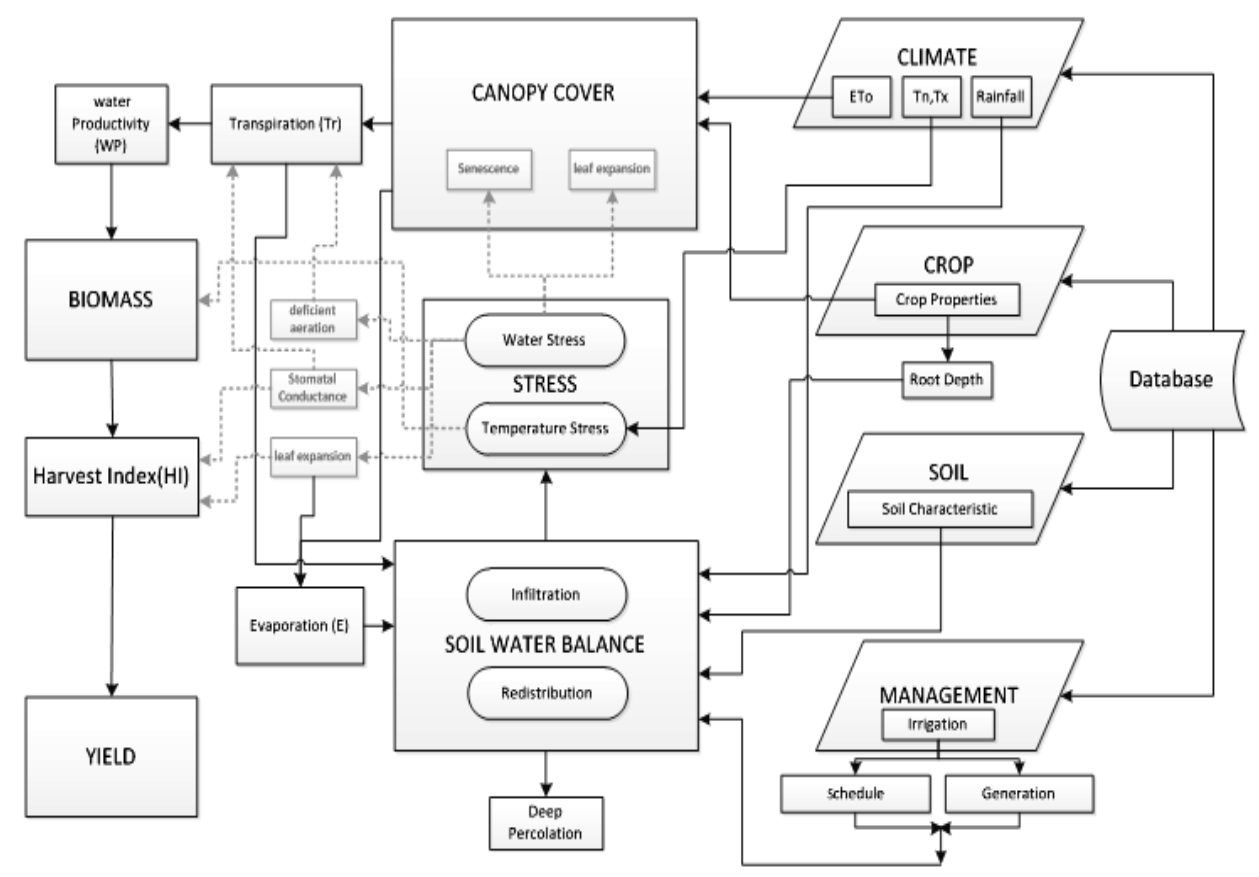

Fig. 3. The functional relationships between the different model components. 
Screen shoots of the "Fruit tree" model inputs, outputs, and options :
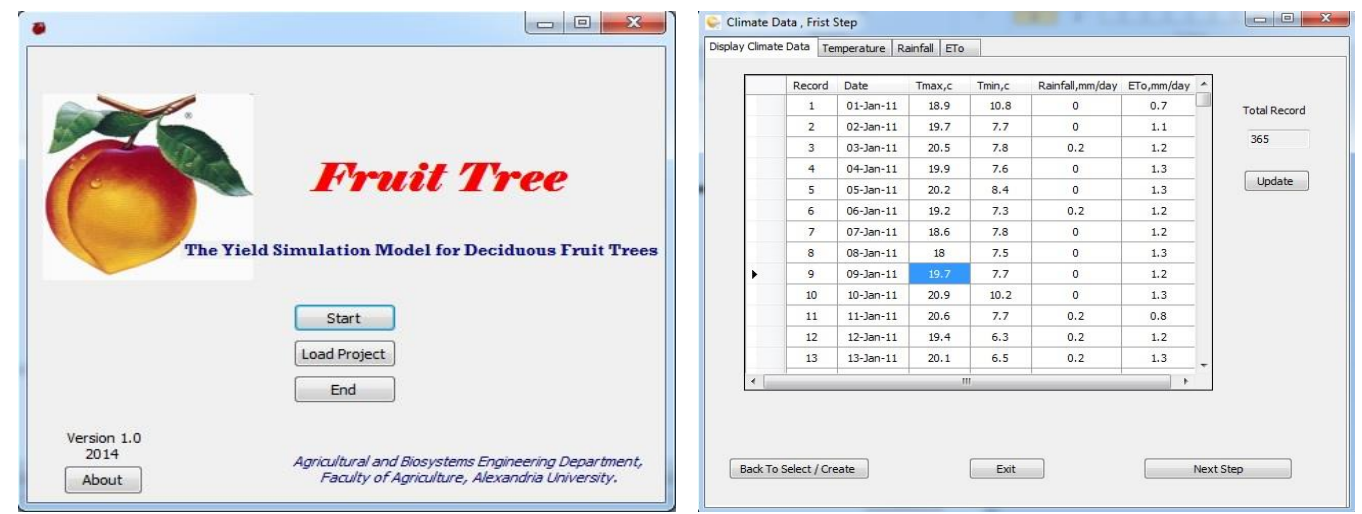

Fig.4. Start the program and climate data input.
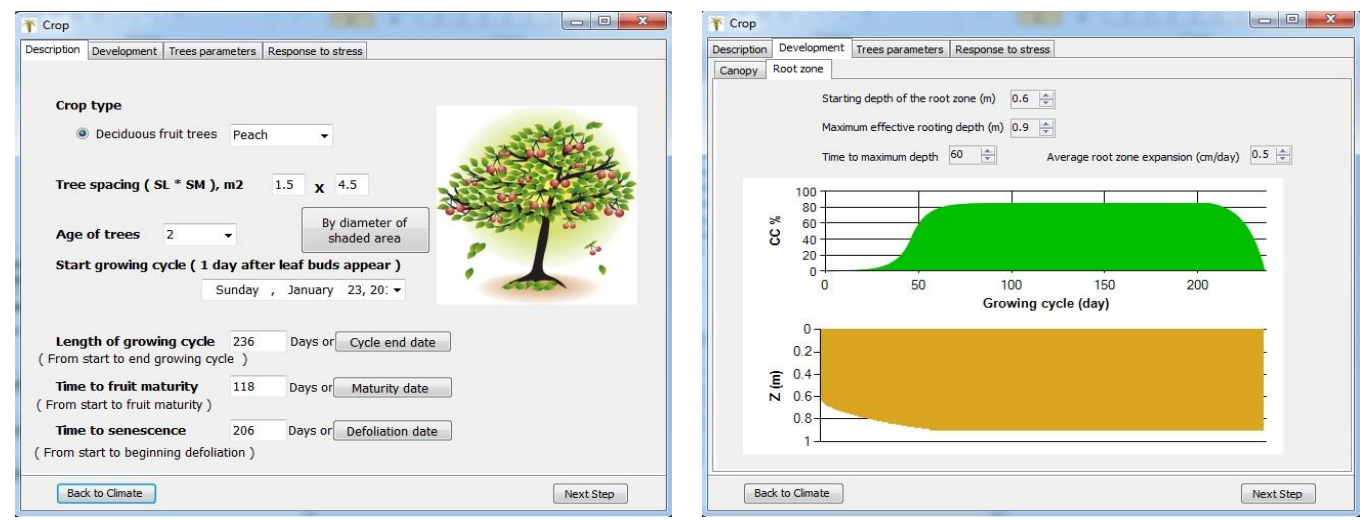

Fig.5. Crop parameters needed
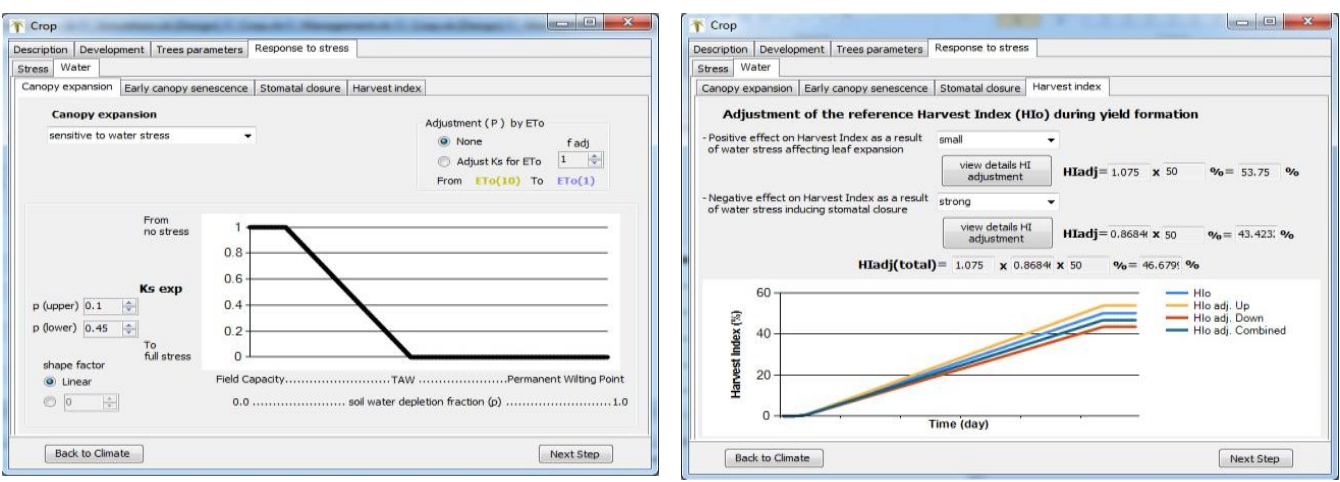

Fig.6. Water stress options. 

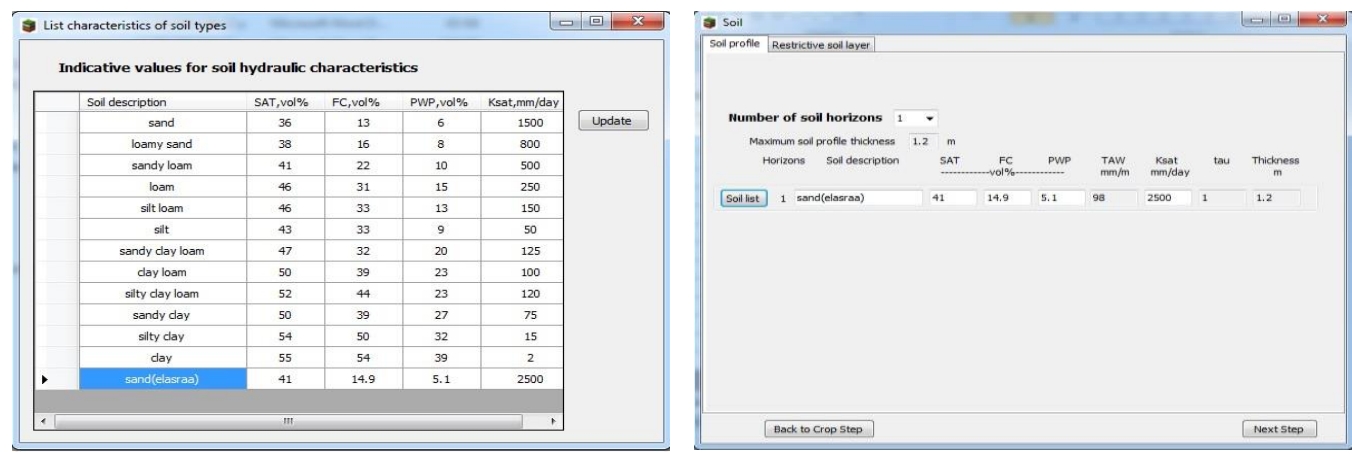

Fig.7. Selection of soil type and soil properties.
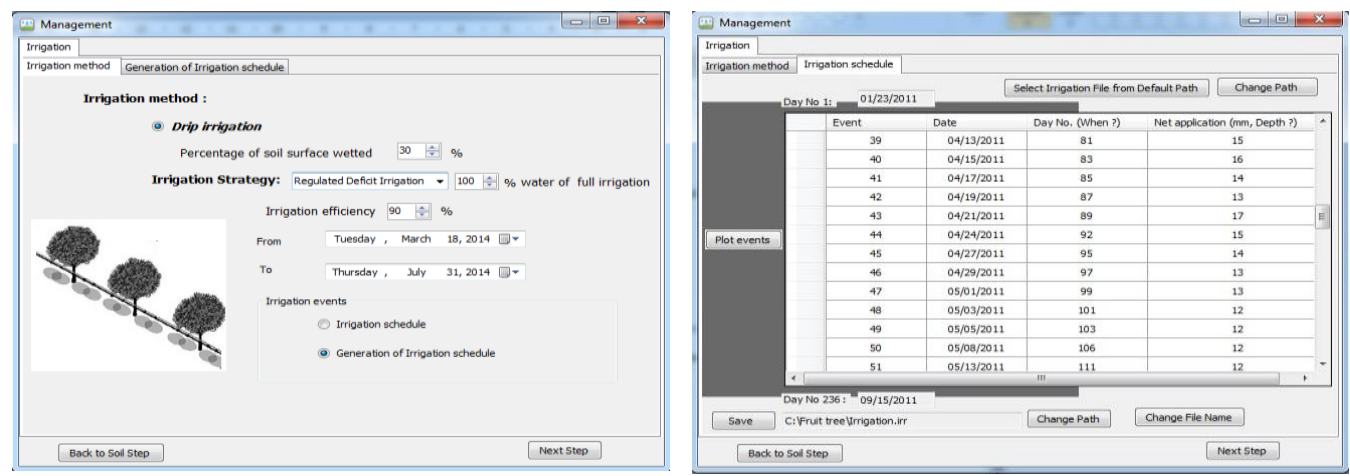

Fig.8. Selection of irrigation strategy and irrigation events.
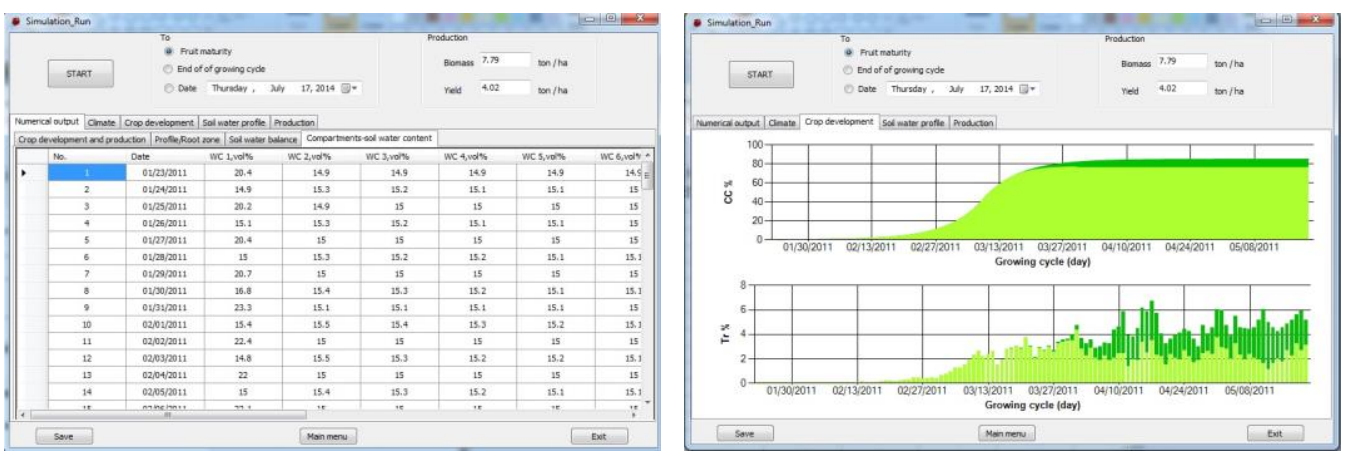

Fig.9. Display of data recorded in output files and graphical displays of green canopy cover and crop transpiration over the growing cycle. 

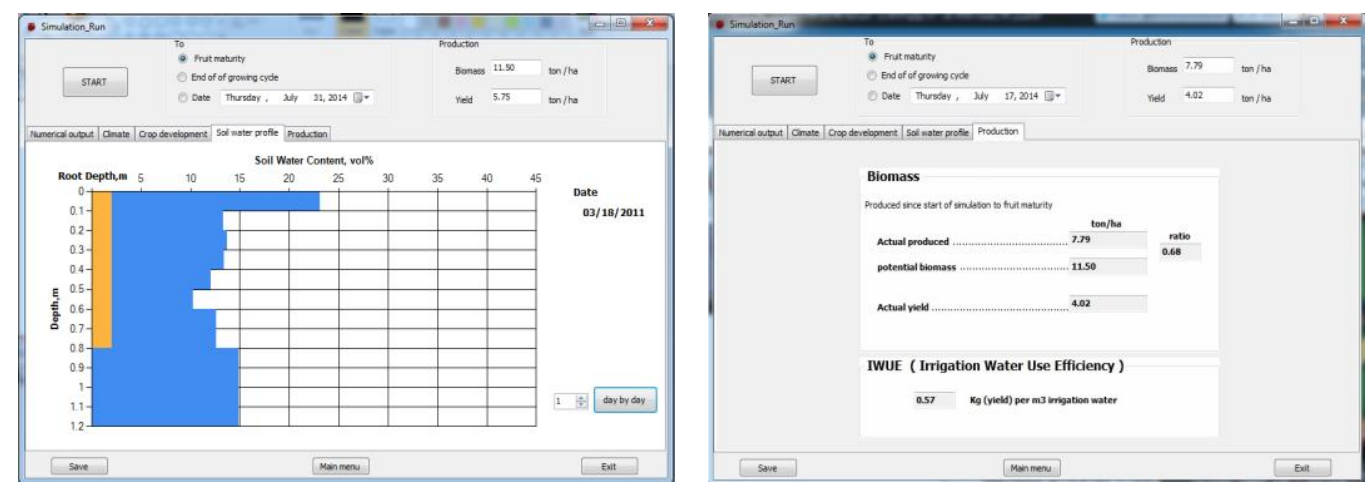

Fig.10. Graphical displays of soil water profile and information on biomass production, actual yield and irrigation water use efficiency.

- Root Mean Square Error (RMSE)

Root mean square error (RMSE) is calculated as follows (Loague and Green, 1991).

Where:

$$
R M S E=\sqrt{\frac{\sum_{i=1}^{n}\left(O_{i}-S_{i}\right)^{2}}{N}}
$$

$\mathrm{Si}$ simulated value,

Oi observed value,

$\mathrm{N}$ number of observations.

The RMSE represents a measure of the overall, or mean, deviation between observed and simulated values, that is, a synthetic indicator of the absolute model uncertainty. For better model performance the value of RMSE should be near to zero.

-Index of agreement (d)

The index of agreement (d) was calculated using the Willmott et al., 1985 equation:

Where:

$$
d=1-\frac{\sum_{i=1}^{n}\left(O_{i}-S_{i}\right)^{2}}{\sum_{i=1}^{n}\left(\left|S_{i}-M O\right|+\left|O_{i}-M O\right|\right)^{2}}
$$

Mo mean of observed value. 
The Index of Agreement (d) developed as a standardized measure of the degree of model prediction error and varies between $-\infty$ and 1 and the model's fit improves as d approaches unity.

Table 2. Conservative (constant) and generally applicable parameters for the simulation of peach productivity, season 2011 and 2012.

\begin{tabular}{|c|c|c|c|}
\hline Description & Symbol & Value & Units \\
\hline $\begin{array}{l}\text {-Climate } \\
\text { Special climatic data for the year } 2011 \text { and } 2012\end{array}$ & & & \\
\hline 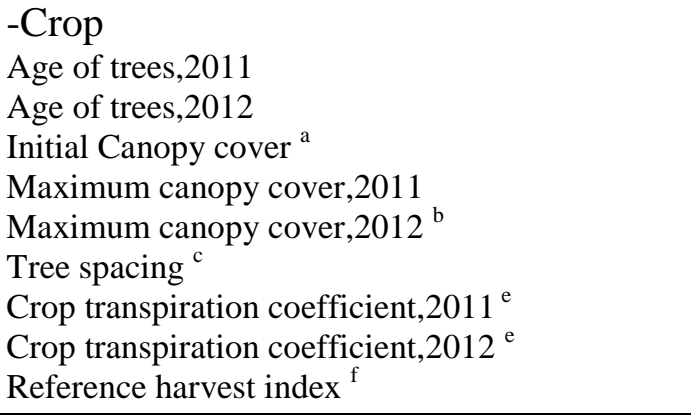 & $\begin{array}{c}\mathrm{CC}_{\mathrm{o}} \\
\mathrm{CC}_{\mathrm{x}} \\
\mathrm{CC}_{\mathrm{x}} \\
\mathrm{Sl}^{*} \mathrm{SM} \\
\mathrm{Kcb}_{\mathrm{x}} \\
\mathrm{Kcb}_{\mathrm{x}} \\
\mathrm{HIo}\end{array}$ & $\begin{array}{c}2 \\
3 \\
0.1 \\
85 \\
100 \\
1.5 * 4.5 \\
0.95 \\
1.1 \\
0.5\end{array}$ & $\begin{array}{c}\text { year } \\
\text { year } \\
\% \\
\% \\
\% \\
\mathrm{~m}^{2}\end{array}$ \\
\hline $\begin{array}{l}\text { - Sensitivity to water stress } \\
\text { Leaf growth threshold } \\
\text { Leaf growth threshold } \\
\text { Leaf growth stress coefficient curve shape } \\
\text { Senescence stress coefficient }\left(\mathrm{p}_{\text {upper }}\right) \\
\text { Senescence stress coefficient curve shape } \\
\left.\text { Stomatal conductance threshold ( } \mathrm{p}_{\text {upper }}\right) \\
\text { Stomata stress coefficient curve shape } \\
\text { Anaerobiosis point }\end{array}$ & $\begin{array}{l}P_{\text {upper }} \\
P_{\text {lower }} \\
f \\
P_{\text {upper }} \\
\quad f \\
P_{\text {upper }} \\
\quad f \\
\Theta_{\text {aer }}\end{array}$ & $\begin{array}{c}0.1 \\
0.45 \\
0 \\
0.45 \\
0 \\
0.45 \\
0 \\
15\end{array}$ & $\begin{array}{c}\text { sensitive to } \\
\text { water stress } h\end{array}$ \\
\hline $\begin{array}{l}\text { Management } \\
\text { Irrigation efficiency }^{c} \\
\text { Percentage of soil surface wetted }{ }^{\mathrm{a}}(\mathrm{C} \text { and RDI) } \\
\text { Percentage of soil surface wetted }{ }^{\mathrm{b}} \text { (PRD) }\end{array}$ & $\begin{array}{l}E a \\
f w \\
f w\end{array}$ & $\begin{array}{l}90 \\
30 \\
15\end{array}$ & $\begin{array}{l}\% \\
\% \\
\%\end{array}$ \\
\hline $\begin{array}{l}\text {-Soil } \\
\text { Number of soil horizons }{ }^{c} \\
\text { soil profile thickness }{ }^{\mathrm{a}} \\
\text { Hydraulic conductivity at saturation }^{c} \\
\text { Volumetric water content at saturationc } \\
\text { Volumetric water content at field capacityc } \\
\text { Volumetric water content at wilting point }^{c}\end{array}$ & $\mathrm{~K}_{\mathrm{sat}}$ & $\begin{array}{c}1 \\
1.2 \\
2500 \\
41 \\
14.9 \\
5.1 \\
\end{array}$ & $\begin{array}{c}\mathrm{m} \\
\mathrm{mm} / \mathrm{day} \\
\% \\
\% \\
\% \\
\end{array}$ \\
\hline
\end{tabular}

${ }^{a}$ Default value; ${ }^{\mathrm{b}}$ Calculated value; ${ }^{\mathrm{c}}$ Measured Value; ${ }^{\mathrm{e}}$ The values in this row are similar to those by Allen et al., 2009; ${ }^{\mathrm{f}}$ The values in this row are similar to those by

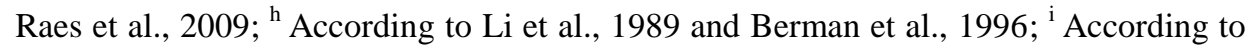
Raes et al., 2011. 


\section{- Correlation coefficient (r)}

The correlation coefficient ( $r$ ) is an indicator of degree of closeness between observed values and model simulated value. The observed and simulated values are found to be better correlated as the correlation coefficient approaches to 1 . The correlation coefficient was estimated by the following equation:

Where:

$$
r=\frac{\sum_{i=1}^{n}\left(O_{i}-M O\right) \times\left(S_{i}-M S\right)}{\sqrt{\sum_{i=1}^{n}\left(O_{i}-M O\right)^{2} \times \sum_{i=1}^{n}\left(S_{i}-M S\right)^{2}}}
$$

MS mean of simulated value.

\section{Model Sensitivity}

To evaluate the model sensitivity to simulate the peach yield, the shortage of irrigation water as a percentage, during the slow fruit growth phase until the maturity, was changed gradually from $100 \%$ to $30 \%$ of the irrigation control treatment water volume.

\section{RESULTS AND DISCUSSION}

The effects of the irrigation strategies; Partial Root-Zone Drying (PRD) and Regulated Deficit Irrigation (RDI) at different levels of water stress, on the peach yield (Ton per ha) in seasons 2011 and 2012 were presented in Table (3) and Fig. (11).

As expected with increased water stress, the yield was decreased as compared with the Control treatment except $\mathrm{PRD}_{75}$ treatment where yield increased in season 2011 and 2012. Also, lower values in yield were found in $\mathrm{RDI}_{75}$ and $\mathrm{RDI}_{50}$ in season 2011 and 2012.

The results in season 2011 showed significant difference between $\mathrm{PRD}_{75}$ and $\mathrm{RDI}_{75}$ and $\mathrm{RDI}_{50}$. The differences between other treatments were not significant. Total yield compared with control treatment was decreased by $32,34.4,10.5$, and $23.39 \%$ for $\mathrm{RDI}_{75}, \mathrm{RDI}_{50}, \mathrm{PRD}_{100}$ and $\mathrm{PRD}_{50}$ treatments and increased by $13.5 \%$ for PRD 75, respectively. 
Regarding to season 2012, C and $\mathrm{PRD}_{75}$ treatments were found significantly different between from $\mathrm{PRD}_{100}, \mathrm{PRD}_{50}, \mathrm{RDI}_{50}$ and $\mathrm{RDI}_{75}$. Total yield from $\mathrm{RDI}_{75}, \mathrm{RDI}_{50}, \mathrm{PRD}_{100}$ and $\mathrm{PRD}_{50}$ treatments were less than the control treatment by 29.6, 28, 17.7 and $27.5 \%$, respectively. Yield value almost doubled from 2011 to 2012 as a result of increased age of the trees.

Yield reduction does not occur under PRD75 treatment that may be as a result of improving the plant environment when water stress was reduced. Water stress in excess of the limit or the increase in water could lead to yield reduction.

The simulated peach yield of the different irrigation treatments were compared with the measured values for season 2011 and 2012 in Table 3, with the deviation of the simulated value from the measured value expressed as a percentage of the measured value and root mean square error (RMSE). Also, index of agreement (d) and the correlation coefficient $(r)$ were presented in the same table for the simulated vs. measured values over the season.

$\Delta$ First Season $\square$ Second Season

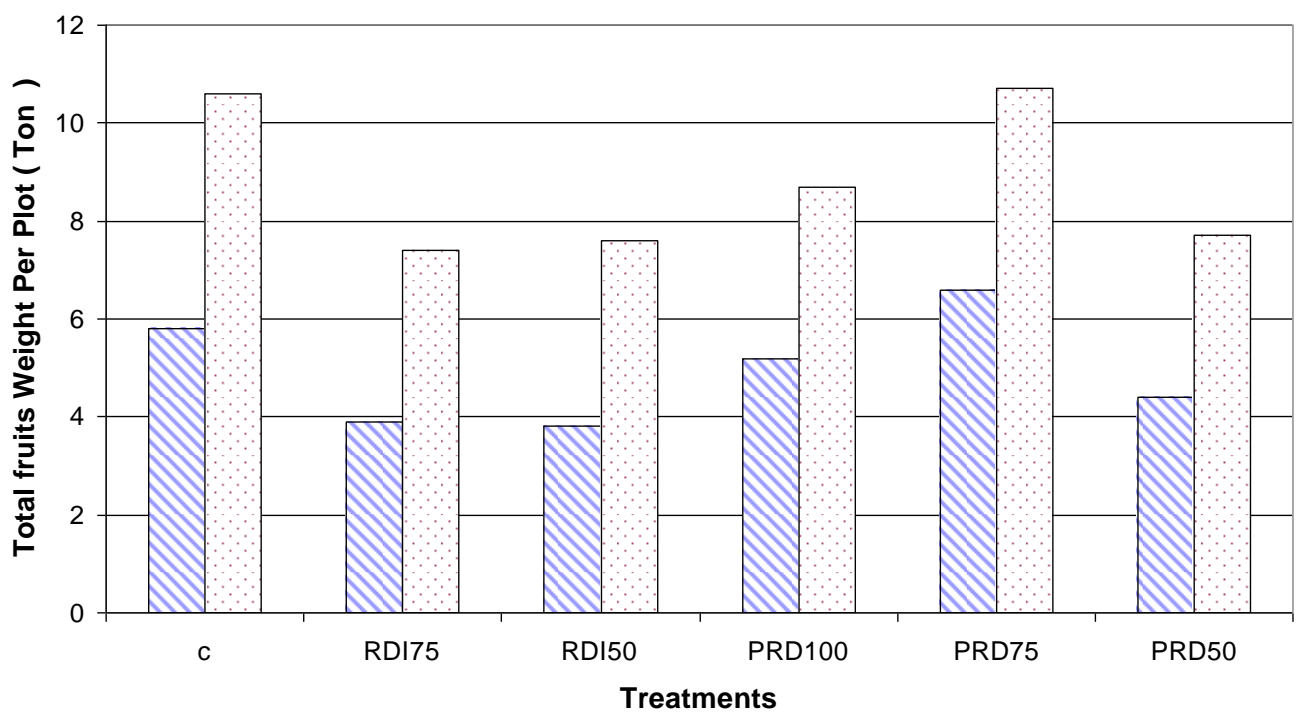

Fig.11.The effect of the irrigation strategies on total fruits weight (Ton per ha) in seasons 2011 and 2012 
It can be seen from Table 3 that when simulated pech yield is compared with the measured values, with 7 out of the 12 values were within $10 \%$ of the measured values, with 4 of the 12 within $5 \%$, and 5 out of the 12 deviating more than $10 \%$, with the largest deviation of $17.82 \%$. Half of the 12 values were overestimated and the other were underestimated.

While the RMSE values were as follows, in total values are low, 7 out of the 12 values were $<1$, and other values did not exceed the value of 1.5 and corresponding to the deviation values of high-value.

The index of agreement $(\mathrm{d})$ and the correlation coefficient (r) were close to 1 in both seasons 2011 and 2012 where 0.903 and 0.825 in season 2011 and 0.867 and 0.833 in season 2012, respectively.

Although many modifications were made to the construction of the AquaCrop model to be able to simulate the yield of peach tree, the simulation model predicted the values of yield under different conditions of water stress and water application strategies.

Simulation model could also predict the yield down due to the increase in irrigation water. This is evident in the yield simulation for season 2012 in PRD100 and PRD75 treatments where Simulated yield 9.22 and 9.27, respectively.

Also, model simulations differentiates between the water deficit resulted from different irrigation strategy "regulated deficit irrigation (RDI) and partial root-zone drying (PRD)" where different output yield depending on irrigation strategy used as shown in table (3).

The peach yield was simulated and its values were estimated (ton/ha) corresponding to the shortage of irrigation water through RDI and PRD irrigation strategy under peach tree conditions in season 2011 and 2012 as shown in table (4).

The water-yield relationship indicator "yield response factor (Ky)" was determined by simulated peach yield data of RDI and PRD. 
The linear relationship of RDI data was presented in Fig. (12) and expressed as:

$$
\left(1-\frac{Y_{a}}{Y_{m}}\right)=1.32\left(1-\frac{E T_{a}}{E T_{m}}\right) \quad R^{2}=0.74
$$

This value of Ky was close to those obtained by Gunduz, M., et al. 2010 and The actual data in this research.

Table 3. Simulated compared with measured values and statistical indices derived for evaluating the performance of simulation model in predicting peach yield for irrigation treatments in season 2011 and 2012.

\begin{tabular}{|c|c|c|c|c|c|c|}
\hline \multicolumn{7}{|c|}{ First season(2011) } \\
\hline Parameters & $\begin{array}{c}\text { Measured } \\
\text { Ton/ha }\end{array}$ & $\begin{array}{l}\text { Simulated } \\
\text { Ton/ha }\end{array}$ & $\begin{array}{c}* \text { Deviation } \\
\%\end{array}$ & $\begin{array}{l}\text { RMSE } \\
\text { Ton/ha }\end{array}$ & D & $\mathrm{r}$ \\
\hline $\mathrm{C}$ & $5.77 \pm 1.21$ & 575 & -0.34 & 099 & \multirow{6}{*}{0.903} & \multirow{6}{*}{0.825} \\
\hline $\mathrm{RDI}_{75}$ & $3.92 \pm 0.64$ & 4.02 & 2.55 & 0.53 & & \\
\hline $\mathrm{RDI}_{50}$ & $3.78 \pm 0.59$ & 3.33 & -11.9 & 0.66 & & \\
\hline $\mathrm{PRD}_{100}$ & $5.16 \pm 0.68$ & 6.08 & 17.82 & 1.06 & & \\
\hline $\mathrm{PRD}_{75}$ & $6.55 \pm 1.13$ & 5.49 & 15.11 & 1.35 & & \\
\hline $\mathrm{PRD}_{50}$ & $4.42 \pm 0.97$ & 4.6 & 4.75 & 0.82 & & \\
\hline \multicolumn{7}{|c|}{ Second season(2012) } \\
\hline Parameters & $\begin{array}{l}\text { Measured } \\
\text { Ton/ha }\end{array}$ & $\begin{array}{l}\text { Simulated } \\
\text { Ton/ha }\end{array}$ & $\begin{array}{c}\text { Deviation } \\
\%\end{array}$ & $\begin{array}{l}\text { RMSE } \\
\text { Ton/ha }\end{array}$ & $\mathrm{D}$ & $\mathrm{R}$ \\
\hline $\mathrm{C}$ & $10.57 \pm 0.39$ & 9.54 & -9.74 & 1.08 & \multirow{6}{*}{0.867} & \multirow{6}{*}{0.833} \\
\hline $\mathrm{RDI}_{75}$ & $7.44 \pm 0.5$ & 7.14 & -4.03 & 0.50 & & \\
\hline $\mathrm{RDI}_{50}$ & $7.61 \pm 0.73$ & 6.45 & -15.24 & 1.29 & & \\
\hline $\mathrm{PRD}_{100}$ & $8.69 \pm 0.06$ & 9.22 & 5.98 & 0.51 & & \\
\hline $\mathrm{PRD}_{75}$ & $10.66 \pm 0.26$ & 9.27 & -13.03 & 1.41 & & \\
\hline $\mathrm{PRD}_{50}$ & $7.66 \pm 0.3$ & 8.07 & 5.35 & 0.47 & & \\
\hline
\end{tabular}

$* \%$ deviation $=($ Simulated - measured $) \times 100 /$ measured . 
Table 4. Simulated yield (ton/ha) Corresponding to the shortage of irrigation water through RDI and PRD irrigation strategy under peach tree conditions in season 2011 and 2012.

\begin{tabular}{|c|c|c|c|c|c|}
\hline season & $\begin{array}{l}\text { Percentage of the } \\
\text { Control irrigation } \\
\text { water volume }\end{array}$ & \multirow{17}{*}{ 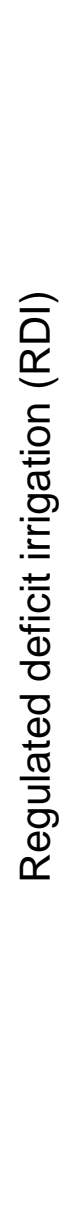 } & $\begin{array}{c}\text { Simulated } \\
\text { yield (ton/ha) }\end{array}$ & \multirow{17}{*}{ 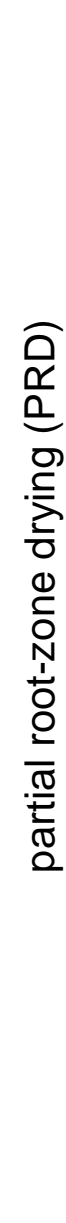 } & $\begin{array}{l}\text { Simulated yield } \\
\text { (ton/ha) }\end{array}$ \\
\hline \multirow{8}{*}{2011} & 100 & & $5.75 \mathrm{a}$ & & 6.08 \\
\hline & 90 & & 4.39 & & 5.75 \\
\hline & 80 & & 4.17 & & 5.6 \\
\hline & 70 & & 3.81 & & 5.33 \\
\hline & 60 & & 3.5 & & 5.14 \\
\hline & 50 & & 3.33 & & 4.63 \\
\hline & 40 & & 3.16 & & 4.2 \\
\hline & 30 & & 2.52 & & 3.51 \\
\hline \multirow{8}{*}{2012} & 100 & & $9.54 \mathrm{a}$ & & 9.21 \\
\hline & 90 & & 7.76 & & 9.39 \\
\hline & 80 & & 7.27 & & 9.28 \\
\hline & 70 & & 6.92 & & 9.09 \\
\hline & 60 & & 6.66 & & 8.54 \\
\hline & 50 & & 6.45 & & 8.07 \\
\hline & 40 & & 6.09 & & 7.27 \\
\hline & 30 & & 4.6 & & 6.66 \\
\hline
\end{tabular}

${ }^{\mathrm{a}}$ control

Also, the linear relationship of PRD data was presented in Fig. (13) and expressed as:

$$
\left(1-\frac{Y_{a}}{Y_{m}}\right)=0.722\left(1-\frac{E T_{a}}{E T_{m}}\right) \quad R^{2}=0.842
$$

Differences resulting values of yield response factor ( Ky ) proves that the peach yield varies in response to irrigation water shortage according to irrigation strategy used. 


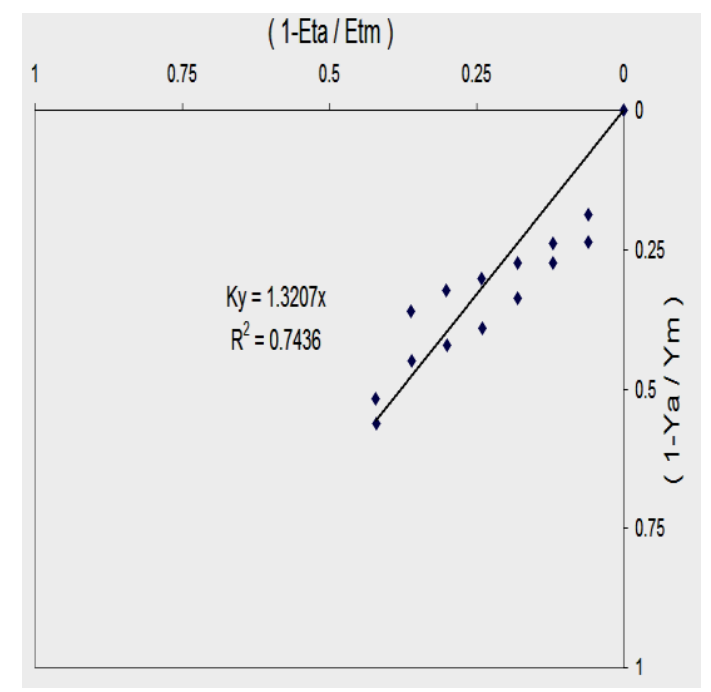

Fig.12.The relationship between the reduction in relative actual crop evapotranspiration and the reduction in relative yield under regulated deficit irrigation (RDI) strategy

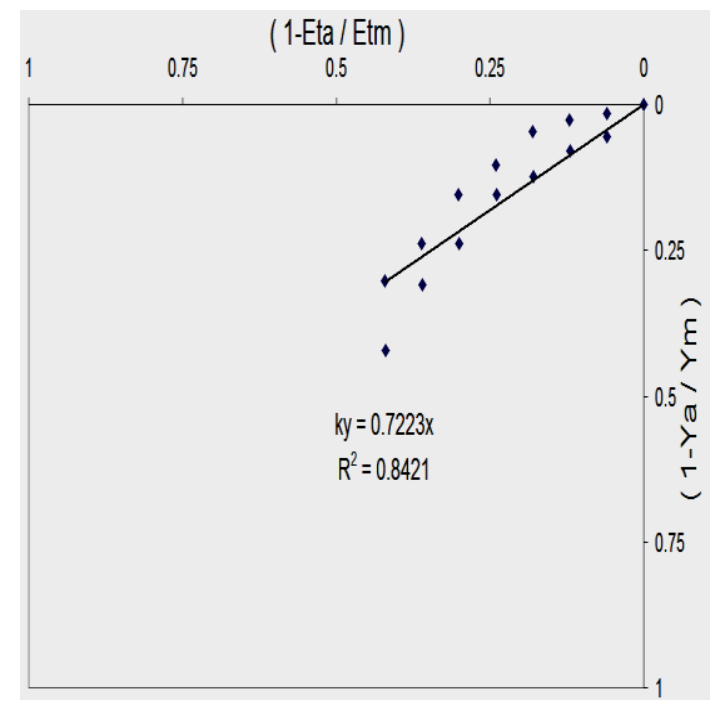

Fig.13.The relationship between the reduction in relative actual crop evapotranspiration and the reduction in relative yield under partial root-zone drying (PRD) strategy

\section{CONCLUSION}

Partial root-zone drying technique has proven its efficiency in quantity of yield as compared with Regulated Deficit Irrigation technique. In 
particular, $\mathrm{PRD}_{75}$ is the recommended treatment to achieve water-saving and maintaining yield.

The modified AquaCrop model was able to predict the value of yield for peach trees in seasons 2011 and 2012 with acceptable accuracy. Also, when tested at different water stress conditions under RDI and PRD, the model was able to estimate the resulting yield by means of yield response factors.

\section{REFERENCES}

Abrisqueta, J.M., Mounzer, O., Álvarez, S., Conejero, W., GarcíaOrellana, Tapia, L.M., Vera, J., Abrisqueta, I., Ruiz-Sánchez, M.C. 2008. Root dynamics of peach trees submitted to partial rootzone drying and continuous deficit irrigation. Agric. Water Manag. 95(8):959-967.

Allen, R. G., \& Pereira, L. S. (2009). Estimating crop coefficients from fraction of ground cover and height. Irrigation Science, 28(1), 1734.

Bear, J. 1972. Dynamics of fluids in porous media. American Elsevier, NY, USA: 338- 346.

Berman, M. E., \& DeJong, T. M. (1996). Water stress and crop load effects on fruit fresh and dry weights in peach (Prunus persica). Tree physiology, 16(10), 859-864.

Carnahan, B., H.A. Luther and J.O. Wilkes 1969. Applied numerical methods. John Wiley \& Sons Inc., NY, USA: 429-444.

Davies, W. J., \& Hartung, W. (2004, September). Has extrapolation from biochemistry to crop functioning worked to sustain plant production under water scarcity. In Proceeding of the 4th International Crop Science Congress (Vol. 26). Brisbane, Australia. 
Doorenbos, J. and A.H. Kassam 1979. Yield response to water. Irrigation and DrainagePaper n. 33. FAO, Rome, Italy, 193 pp.

FAO. 2012. FAOSTAT online database, available at link http://faostat.fao.org/. Accessed on December 2013.

Ferreres, E. and Castel, J.R. 1981. Drip irrigation management. Division of Agricultural Sciences, University of California. Publication leaflet 21259.

Fereres, E., Martinich, D.A., Aldrich, T.M., Castel, J.R., Holzapfel, E. \& Schulbach, H.1982. Drip irrigation saves money in young almond orchards. California Agriculture 36:12-13.

Gunduz, M., Korkmaz, N., Asik, S., Unal, H. B., \& Avci, M. (2010). Effects of Various Irrigation Regimes on Soil Water Balance, Yield, and Fruit Quality of Drip-Irrigated Peach Trees. Journal of Irrigation and Drainage Engineering, 137(7), 426-434

Kriedemann, P. E., \& Goodwin, I. (2003). Regulated deficit irrigation and partial rootzone drying. Canberra: Land \& Water Australia.

Li, S. H., Huguet, J. G., Schoch, P. G., \& Orlando, P. (1989). Response of peach tree growth and cropping to soil water deficit at various phenological stages of fruit development. J. Hort. Sci, 64(5), 541552.

Loague, K. and Green, R.E. 1991. Statistical and graphical methods for evaluating solute transport models; overview and application. J. Contam. Hydrol, 7:51 73.

Mannocchi, F. and Mecarelli, P. 1994. Optimization analysis of deficit irrigation systems. Journal of Irrigation and Drainage Engineering 120: 484-502. 
McCarthy MG.1997. The effect of transient water deficit on berry development of cv. Shiraz (Vitis vinifera L.). Australian Journal of Grape and Wine Research 3, 102-108.

Moral, F. J., López-Rodríguez, F., Cuadrados, F., \& Celma, A. R. (2009). Computer-assisted sizing of photovoltaic systems for drip irrigation of olive orchards in semi-arid climate. Spanish Journal of Agricultural Research, 7(3), 503-512.

Moutonnet, P. (2002). Yield response factors of field crops to deficit irrigation. Water Reports, FAO - ISBN 92-5-104768-5 ISSN 10201203. p. $11-15$

ORGAZ F., FERERES E., 1998. Riego. In: El cultivo del olivo (Barranco D., Fernández-Escobar R., Rallo L., eds). Consejería de Agricultura y Pesca de la Junta de Andalucía. Seville, Spain. [In Spanish].

Raes, D., Steduto, P., Hsiao, T. C., \& Fereres, E. (2011). Reference manual, chapter 2-AquaCrop version 3.1. Accessed online at http://www. fao. org/nr/water/docs/aquacrop3_1/AquaCrop V31Chapter2. pdf on April.

Raes, D., Steduto, P., Hsiao, T., and Fereres, E. (2009). Chapter 3: Calculation Procedure. . AquaCrop Reference Manual Version 3.1.

Raes, D., Steduto, P., Hsiao, T., and Fereres, E. (2012). Chapter 3: Calculation Procedure. AquaCrop Reference Manual Version 4.

Steduto, P., Hsiao, T. C., Raes, D., \& Fereres, E. (2011). AquaCropThe FAO crop model to simulate yield response to water. Reference Manual, Chapter 1 - AquaCrop, Version 3.1plus January 2011 RAES, D., FAO Land and Water Division, FAO, Rome. 
Steduto, P., Hsiao, T. C., Fereres, E., \& Raes, D. (2012). Crop Yield Response to Water-FAO Irrigation and Drainage Paper 66. Food and Agriculture Organization of the United Nations, Rome, Italy.

Steduto, P., Hsiao, T.C., Raes, D. and Fereres, E. 2009. AquaCrop-The FAO crop model to simulate yield response to water: I. Concepts and underlying principles. Agronomy Journal, 101(3): 426-437

Willmott CJ, Ackleson SG, Davis RE, Feddema JJ, Klink KM, Legates DR, O'Donnell J, Rowe CM. 1985. Statistics for the evaluation of model performance. Journal of Geophysical Research0o 90(C5): 8995-9005

\section{الملخص العربي - n}

تعديل نموذج منظمة الأغذية والزراعة "FAO" لمحاكاة إستجابة المحصول

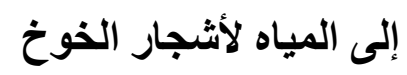

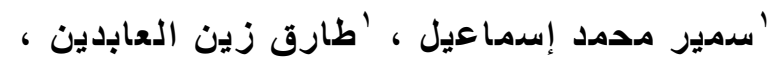

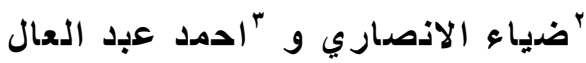

علي الرغم ان برنامج ال AquaCrop لديه كثير من المميزات في التنبؤ بالمحصول للمحاصيل

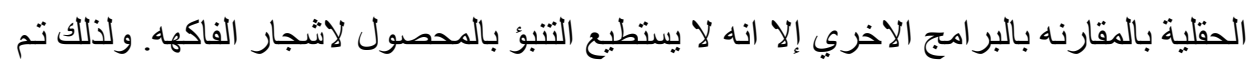

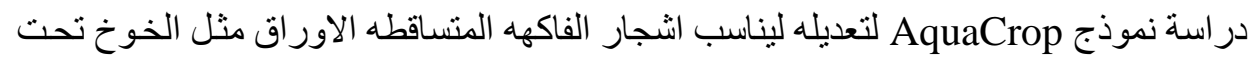

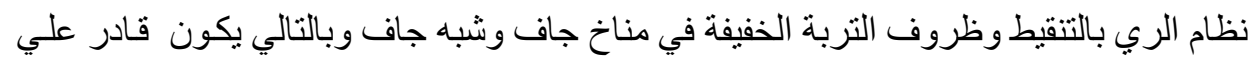

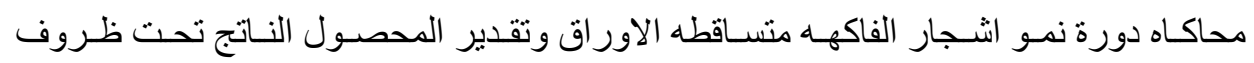

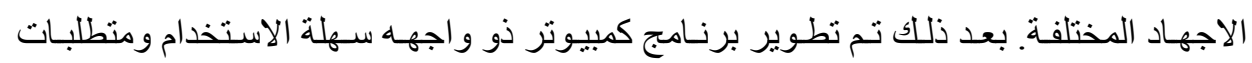

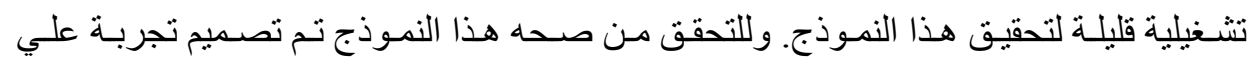

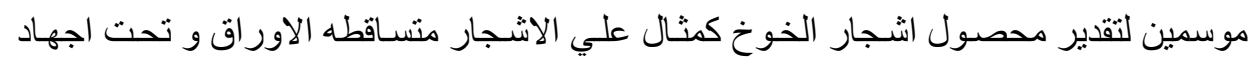

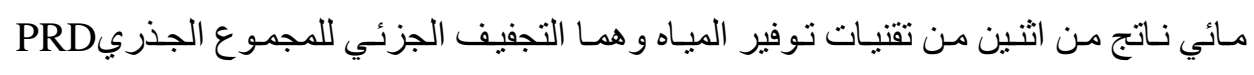

ا أستاذ هندسة نظم الري، قسم الهندسة الزراعية، كلية الزراعة، الثاطبى، جامعة الإسكندرية.

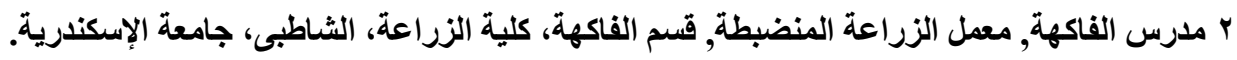

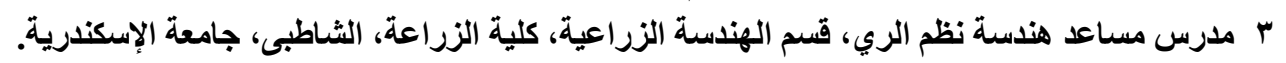




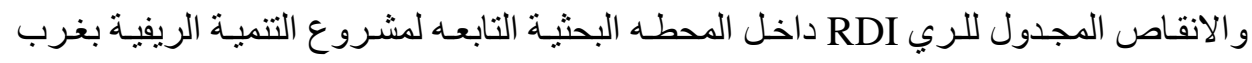

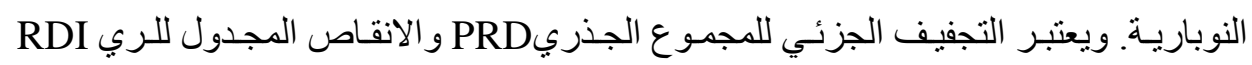

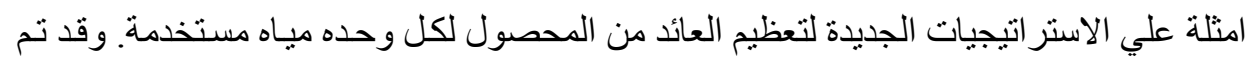

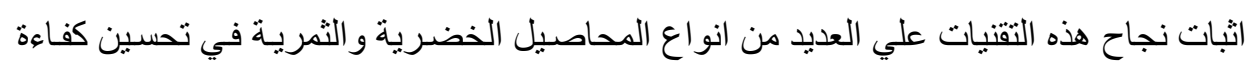

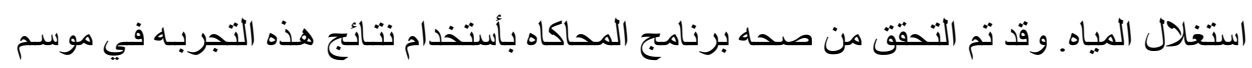

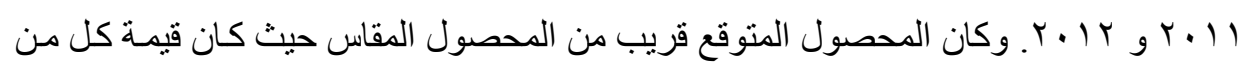

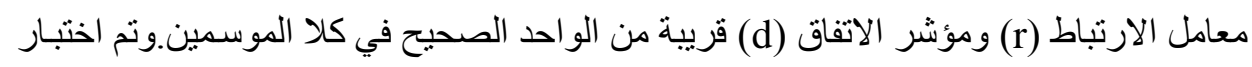

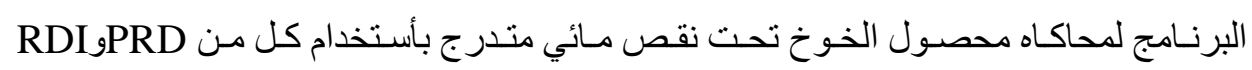

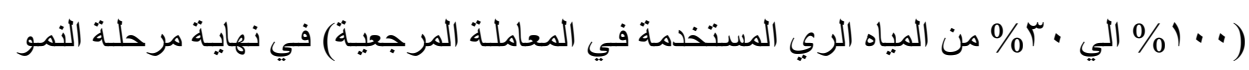

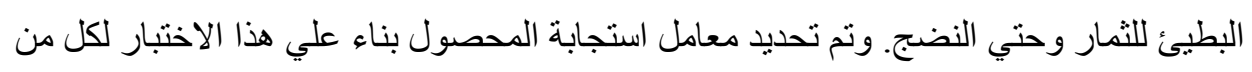
PRDوRDI 